\title{
Teachers' Integration of Information and Communication Technology (ICT) Tools into Writing Classes: A Qualitative Study
}

Luqman M. Rababah*

\begin{abstract}
Integration of ICT is invaluable in writing classes as it affects the writing abilities of students positively and improves their EFL writing. This study has made use of qualitative design. Ten EFL teachers have been chosen based on the convenience sample to answer the research questions. Using the observation tool, this study has been carried out in the first semester of the academic year 2018/2019. The participants were all from private secondary school stages in Irbid, Jordan where the ICT infrastructure is available in the classrooms. The observations revealed that the observed teachers integrate various media and technologies in their instruction in classrooms. Further studies are recommended to compare between public and private schools in terms of the integration of ICT tools.
\end{abstract}

Keywords: ICT, EFL writing, creativity, constructivism, integration.

\section{Introduction}

Majority of researchers are advocates of Information Communication Technology (ICT) tools integration into teaching and learning in EFL/ESL settings (Al-Haq \& Al-Sobh, 2010; Strassman \& D'Amore, 2002; Rababah, 2018; Wooley, 2007; Yang, 2004). They do believe that these tools are effective teaching tools which are useful in teaching EFL writing. The use of these tools may generate enhanced achievement compared to the traditional methods as ICT tools are enriched with information where students can take advantage of in learning and in improving their writing.

There are several reasons why ICT tools are useful in ESL/EFL classrooms. First, these tools improve the achievement of students and they provide students with authentic materials, global awareness, experiential learning, global understanding and environmental friendliness. Second, they motivate EFL students' writing creativity (Al-Jarf, 2007; Meloni, 1997; Rababah, Alshehab \& BaniMelhem, 2018; Rababah \& Rababah, 2017).

ICT is invaluable in writing classes as it affects the writing abilities of the students positively and improves their EFL writing creativity, tackles their individual differences, assists in tearing down the barriers that student's face in learning, and saves students' time and effort. It also provides students with instantaneous feedback about their performance. Despite ICT's importance to EFL students in writing classes, few studies have been found investigating the actual use of the ICT tools particularly in Jordan (AIHaq and Al-Sobh, 2010; Rababah, 2018, Rababah \& Banikalef, 2019). Thus, this study tries to answer these research questions by using the observation instrument.

\footnotetext{
* School of Arts and Languages, Jadara University, Jordan

Corresponding Email: rababah80@gmail.com
} 
1) What ICT tools are utilized in the classrooms to improve EFL students' writing?

2) How do EFL lecturers employ ICT tools in writing classes?

\section{Literature review}

According to prior literature, ICT tools could improve EFL students' writing (Al-Jarf, 2007; Castellani \& Jeffs, 2001; Majid et al., 2003; Meloni, 1997; Rababah \&Almwajeh, 2018; Strassman \& D'Amore, 2002; Wooley, 2007; Yang, 2004). These authors revealed that web-based tools, word processors, computer programs, e-mail, computer networks, the Internet and online journaling were used to develop ESL as well as EFL students'writing skills.

To begin with, Al-Haq and Al-Sobh's (2010) study attempted to determine the effect of web-based writing instructional EFL program (WbWIP) upon the performance of secondary students in Jordan. Based on the results, a significant difference exists among the student's achievements mean scores of post test for the content component in the experimental as opposed to the controlled group. Meanwhile, Al-Jarf (2007) examined the effect of online courses on non-native freshman students' poem and short stories' writing in EFL. The results revealed that online learning environment positively impacted the students' creativity and attitudes towards learning.

Similarly, Wooley (2007) studied the impacts of web-based peer review in the context of students' writing online through an asynchronous peer review system. He found that students providing elaborate feedback with free form comments outperformed those who provided numerical ratings. Also, Yang (2004) examined the effectiveness of utilizing "My Access" in three various contexts. She revealed that even though many of the students revealed positive sentiments towards the automated essay-grading mechanism, they feel that fixed, repeated feedback eventually becomes meaningless. Almost $90 \%$ of the students participating in the study liked the program as it enabled them to revise their essays while $85 \%$ liked receiving a score directly after they submit their essay.

In a related study, Al-Jarf (2004) studied the effect of online learning on struggling EFL college writers. Analysis through ANCOVA highlighted significant differences between the experimental and control groups when it comes to proficiency, less errors and creative communication with the former group outperforming the latter. In another related study, Majid et al. (2003) attempted to examine the Internet use and SCAMPER in the facilitation of creative writing. Their findings revealed that students who made use of the Internet improved in their creative writing with regards to fluency and elaboration. Finally, Tsou et al.'s (2002) study looked into the impact of web-based writing program called My Access'. The results of their study showed that students using the program outperformed those who are regular writers in terms of content, development and organization.

\section{Methods}

This study has made use of qualitative design. Ten EFL teachers have been chosen based on the convenience sample to answer the research questions. The participants were all from private secondary school stages in Irbid, Jordan where the ICT infrastructure is available in the classrooms. This study has been carried out in the second first semester of the academic year 2018/2019. The study has employed the observation tool in order to collect data and find out the actual integration of ICT tools in EFL classroom. The pseudonym has been used to hide the identities of the observed teachers and instead the researcher used some codes. 


\section{Results}

The aim of this qualitative study was to identify the integration of ICT tools in EFL writing among teachers of private secondary schools in Irbid, Jordan.

\section{Research Question One: What ICT tools are utilized in the classrooms to improve EFL students' writing?}

The observations revealed that observed teachers integrate various media and technologies in their instruction in classrooms. Based on the observations, all the teachers employed a combination of media and technologies in their writing classes to facilitate students' enhancement of writing ability. These technologies included e-mail, word processors, e-content of English language among others.

The integration of ICT into writing classes as displayed by the teachers is presented in Table 4.1.

Table 1 Teachers' Integration of ICT Tools into Writing Classes

\begin{tabular}{|c|c|c|c|c|c|}
\hline \multirow{2}{*}{$\begin{array}{l}\text { ICT integrated } \\
\text { Teachers }\end{array}$} & E-mail & \multicolumn{2}{|c|}{ Word processor } & \multirow[t]{2}{*}{ E-content } & \multirow[t]{2}{*}{ Other } \\
\hline & Integrating ICT tool & $Y E S=Y$ & $\mathrm{No}=\mathrm{N}$ & & \\
\hline TA & Y & Y & & Y & Y \\
\hline TB & $\mathrm{N}$ & Y & & Y & Y \\
\hline $\mathrm{TC}$ & Y & Y & & Y & $\mathrm{N}$ \\
\hline TD & Y & Y & & Y & Y \\
\hline TE & Y & Y & & $\mathrm{N}$ & $\mathrm{N}$ \\
\hline $\mathrm{TF}$ & $\mathrm{N}$ & Y & & $\mathrm{Y}$ & Y \\
\hline TG & Y & $\mathrm{Y}$ & & $\mathrm{Y}$ & $Y$ \\
\hline $\mathrm{TH}$ & Y & Y & & $\mathrm{N}$ & $\mathrm{N}$ \\
\hline $\mathrm{TI}$ & Y & Y & & Y & Y \\
\hline TJ & Y & $\mathrm{N}$ & & Y & Y \\
\hline$N=10$ & 8 & 9 & & 8 & 7 \\
\hline $\begin{array}{c}\text { Total for each sub-theme in } \\
\text { percentage } \%\end{array}$ & $80 \%$ & $90 \%$ & & $80 \%$ & $70 \%$ \\
\hline
\end{tabular}


The above table shows that the top ICT tool employed by the teachers is word processor. Using e-mail and e-content courseware takes second place to be integrated. Other ICT tools such as PowerPoint and smart boards take third place in the preference of teachers.

\section{Research Question two: How do EFL lecturers employ ICT tools in writing classes?}

Based on the observations, the researcher observed that TA (Observation, December 6, 2018) used the word processor as a tool in the computer lab. He also organized the students' schedule of using the computer lab where every student is appropriated his/her own computer. TA revised prior knowledge learned in class to help students link between what they've learned and what they were presently learning, and the benefit of the technology to writing. TA showed the students a formal letter model and he requested them to start their writing. Once finished, they were provided the opportunity to check their spelling and grammar with the help of the provided spelling checker.

TD (Observation, December 18, 2018) was also observed to use e-content of English language in his class instructions. The teacher managed the class really well. The lab was equipped by 26 computers arranged along the walls with an open space in the middle. This way the teacher is able to view individual screens as they worked on the class task. The majority of the students were focused on their task but a few of them lost interest and began playing games. The teacher set them immediately back on track. Students who completed the task moved on the second phase of writing questions. Those who felt it too difficult to write, they selected another topic and continued to write (TD, Observation, December 18, 2018).

\section{Discussion, conclusion and recommendations}

It was evident from the observation that teachers integrate several media and technologies in their classroom instruction. All the teachers were observed to integrate one of ICT tools in their writing classes. Regarding the adopting of integration of ICT, the results show that the top ICT tool employed by the teachers is the word processor followed by the e-mail and e-content and other tools. The teachers use a combined set of media and technologies to enable their writing ability. They use technologies including e-mail, word processors, e-content of English language, with the most commonly used as the word processor followed by e-mail and e-content.

From the point of view of technology integration, ICT integration into classrooms is aligned with constructivism theory (Doolittle \& Hicks, 2003; Franklin \& Molebash, 2007). Constructivism, a theory derived from the theories Piaget and Vygotsky proposed, provides a distinct perspective on knowledge and learning. This is reinforced by Vygotsky's (1978) premise of the significance of social dialogue. Specifically, Vygotsky (1978) supports the dynamic social process of learning where the teacher communicates with the student while focusing on emerging skills and abilities. In the context of e-mails, the teacher and the students enter into a partnership in cognitive activities as they meaningfully interact through communication. This process is described as a dialogic one and it is advantageous to both teachers and students as both learn from each other through the social process. Previous studies have found that ICT tools have positively impact on writing (AI-Haq \& Al-Sobh, 2010; Razak \& Lee, 2012; Tooranposhti \& Gholamzadeh, 2011).

For future research, an investigation into public schools where MoE policy on writing is applied, is recommended for future studies to determine if similar integration of ICT is being followed and the success of the instruction. A comparison between private schools and public schools would highlight the differences in instruction and yield significant information concerning the enhancement of students' writing. 


\section{References}

Al-Haq, F. \& Al-Sobh, A. (2010). The effect of a web-based writing instructional EFL program on enhancing the performance of Jordanian secondary students. JALT CALL, 6 (3), 189-218.

Al-Jarf, R. (2007). Online instruction and creative writing by Saudi EFL freshman students, King Saud University, Saudi Arabia. Asian EFL Journal, 22 (1), 92-107.

Al-Jarf, R. (2004). Effect of online learning on struggling ESL college writers. Foreign Language Annals, 37(1), $49-57$.

Castellani, J., \& Jeffs, T. (2001). Reading and writing: Teaching strategies, technology tools, and the Internet. Teaching Exceptional Children, 33(5), 60-67.

Doolittle, P.E., \& Hicks, D. (2003). Constructivism as a theoretical foundation for the use of technology in social studies. Theory \& Research in Social Education, 31(1), 72-104.

Franklin, C.A., \& Molebash, P.E. (2007). Technology in the elementary social studies classroom: Teacher preparation does matter. Theory \& Research in Social Education, 35(2), 153-173.

Majid, D., Tan, A-G., \& Soh, K-C. (2003). Enhancing children's creativity: An exploratory study on using the Internet and SCAMPER as creative writing tools. Korean Journal of Problem Solving, 13, 67-81.

Meloni, C. (1997). Armchair travelers on the information superhighway. In T. Boswood (Ed.). New Ways of Using Computers in Language Teaching, 120-146. Alexandria, VA: TESOL.

Rababah, L. (2018). An adapted version of Torrance test of creative thinking (TTCT) in EFL/ESL writing: A rubric scoring and a review of studies. International Journal of English and Education, 7(2), 128-136.

Rababah, L., \& Banikalef, (2019). The use of valuing strategies into enhancing creativity in EFL writing. Education and Linguistics Research, 5 (1), 30-36.

Rababah, L., \& Almwajeh, M. (2018). Promoting creativity in EFL/ESL writing through scaffolding strategy. International Journal of English and Education, 7(3), 148-160.

Rababah, L., Alshehab, M., \& Bani Melhem, N. (2018). Exploring the Factors that Hinder Jordanian Students in Developing Creativity in EFL Writing. International Journal of English and Education (IJEE), 7(3), 161-170.

Rababah, I., \& Rababah, L. (2017). Investigating Arabic to Speakers of Other Languages (ASOL) Lecturers' Attitudes towards Utilizing Flipped Classroom Instruction ( $\mathrm{FCl}$ ): A Qualitative Study at Jordanian Public Universities. International Education Studies, 10(7), 94-104.

Razak, R.A., \& Lee, C.M. (2012). Promoting Higher Order Thinking In Chinese Language Literary Text via Online Social Network. Journal of Education and Practice, 3(16), 199-209.

Strassman, B., \& D'Amore, M. (2002). The write technology. Teaching Exceptional Children, 34, 28-31.

Tooranposhti, M. \& Gholamzadeh, M. (2011). The effect of education of computer on creativity. Presented at the International Conference on Humanities, Society and Culture, Singapore. Retrieved from http://www.ipedr.com/vol20/34-ICHSC2011M10014.pdf 
Tsou, M.H., Guo, L., Stow, D., \& Kaiser, J. (2002). Web-based geospatial information services and analytical tools for natural habitat conservation and management. Final Report For NASA Affiliated Research Center. San Diego, CA: San Diego State University.

Vygotsky, L. (1978). Interaction between learning and development. Readings on the development of children, 23(3), 34-41.

Wooley, R. (2007). The Effects of Web-Based Peer Review on Student Writing (Unpublished Doctoral dissertation). Kent State University, USA.

Yang, N. (2004). Using my access in EFL writing. The proceedings of the 2004 International Conference and Workshop on TEFL \& Applied Linguistics. Taipei: Ming Chuan University. 